\section{Prof. A. O. R. Windaus}

ON June 9 it was reported from Göttingen that Adolf Windaus had died in his eighty-third year. He had retired as professor and director of the University Chemical Laboratory at Göttingen in 1938, and was made emeritus professor and director in 1944 .

Windaus was born in Berlin in 1876, educated at the Universities of Berlin and Freiburg-im-Bresgau and became Privatdozent in 1903. After a short period at Innsbruck, he was elected to Göttingen in 1915. He was awarded the Nobel Prize for Chemistry in 1928, and also received the Baeyer, Pasteur and Goethe Medals.

To those interested in steroids, Windaus's name will stand with that of the late Heinrich Wieland as the greatest in the period of German pre-eminence in discovery about the chemistry and physiology of these substances. Most of his publications between 1903 and 1928 were about cholesterol and described, inter alia, the preparation of complexes with digitonin, solanin, etc. $(1909,1918)$, the nature of the sidechain (1913) and the relationship to coprosterol (1916) and to the bile acids (1919). Papers also appeared on stigmasterol $(1906,1924)$, sitosterol (1918, 1924), hydrodeoxycholic acid (1923, 1926), chenodeoxycholic acid $(1924,1925,1926)$ and on ' $\beta$ '-phocæcholic acid (1928). All this work and much more, including some on heart poisons and saponins, was done without modern knowledge of steroid formulæ; yet Windaus's fundamental discoveries stand largely unchallenged to-day. His work on seymnol (with W. Bergmann and G. König, Hoppe Seyl. Z., 189, 148; 1930) was the first on the chemistry of this substance. The paper with Alfred Hess, of Columbia University, New York, entitled "Sterine und antirachitisches Vitamin" and published at the session of the Gesellschaft der Wissenschaften zu Göttingen on January 28, 1927, clearly recognized that both ergosterol and an impurity separable from cholesterol acquired antirachitic activity on irradiation with ultra-violet light. Parallel work had already begun in England (for example, I. M. Heilbron, E. D. Kamm and R. A. Morton; O. Rosenheim and T. A. Webster; Chem. and Indust., $45,932 ; 1926)$; it was energetically pursued there, and also by Windaus and his colleagues until, in 1931, success in isolating a pure vitamin $D$ was announced almost simultaneously from Göttingen and Hampstead, London. From irradiated ergosterol, F. A. Askew, H. M. Bruce, R. K. Callow, J. St. L. Philpot and T. A. Webster (Nature, 128, $758 ; 1931$ ) obtained calciferol, and Windaus and $O$. Linsert (Liebigs Ann., 489, 269; 1931) vitamin $\mathrm{D}_{2}$ : these substances were later found to be identical, although the separate names were retained.

'Vitamin $D_{1}$ ', originally reported as pure by the German workers (Liebigs Ann., 489, 252; 1931), was later proved (ibid., 493, 259 ; 1932) to be a molecular compound of vitamin $\mathrm{D}_{2}$ and lumisterol.

For Windaus, this was by no means the end of the vitamin D problem. Doubts as to the identity of calciferol (vitamin $\mathrm{D}_{2}$ ) and the antirachitic vitamin of fish-liver oils persisted, and C. E. Bills (Physiol. Rev., 15, 1; 1935) summarized evidence that the antirachitic vitamin in irradiated (impure) cholesterol and in cod liver oil (as measured in 'rat units') is more potent for chicks than the vitamin (calciferol) in irradiated ergosterlly.

Windaus brilliantly recalled that J. Mauthner and W. Suida in 1896 (Mh. Chem., 17, 579) had oxidized cholesterol with chromic acid to 7-ketocholesterol, and, with H. Lettré and Fr. Schenck (Liebigs Ann., $520,98 ; 1935)$, he reported the conversion of this substance into 7-dehydrocholesterol. Irradiation of this gave a mixture from which was isolated (Windaus, Fr. Schenck and F. von Werder : Hoppe Seyl. Z., 241,100 ; 1936) vitamin $D_{3}$, identical with the natural vitamin obtained from tunny liver oil by H. Brockmann (Hoppe Seyl. Z., 241, 104; 1936) at Göttingen. Windaus's later papers were about the chemical nature of natural forms of vitamin $D$ and the chemistry of irradiation products of ergosterol and 7-dehydrocholesterol.

Windaus's publications, which ceased in 1944, remain as an inspiring example of what a great intellect can still accomplish in scientific discovery. G. A. D. Haslewood

\section{Dr. F. Busemann}

Dr. Felix Busemann, who died on April 30 at the untimely age of fifty-one, was an outstanding authority in his chosen subject, electrical transmission, as is his brother, Adolf Busemann, one of the leading German aerodynamicists now in America. Trained at the Institute of Technology, Darmstadt, he became later assistant to the professor of electrical machine design there, and in 1934 joined the firm of Siemens Schuckert in Berlin, becoming one of a team concerned with future developments in electrical trans. mission. This team had as one of its assignments that of high-voltage direct-current transmission. Starting with a pilot scheme between Charlottenburg and Moabit, it followed by planning the Siemens Schuckert half of the major Elbe-Berlin project. After the Second World War, Dr. Busemann was chosen by the Darwin Panel and came to Britain in 1946 to report on the German work in this field.

Busemann found the social climate in Britain so akin to his temperament that he shortly accepted an offer to join the staff of the Electrical Research Association and continue his studies on d.c. transmission. These resulted in a masterly series of fourteen reports covering all aspects of the subject with the exception of valves, for the study of which facilities were lacking. He played a major part in the planning of a pilot scheme which, had it matured, would have placed Great Britain in the van of development. He was without doubt the foremost authority on high-voltage direct-current transmission in Britain, and his loss will be greatly felt.

With the temporary cessation of interest in directcurrent transmission, Busemann turned his versatile mind to other aspects of transmission. Among these he devised, jointly with W. Casson, a classic programme of full-scale experiments on power-system stability (Cliff Quay), described in a paper before the Institution of Electrical Engineers last year. More recently, he had been concerned with mechanical and thermal properties of soil and utilization of power cables. To all these he brought quick appreciation of decisive factors and great facility in analysis and exposition.

Behind a natural modesty Busemann had great personal charm and humour as well as perception. He was a musician of almost professional attainment and gave much service to his church and the social activities of the Electrical Research Association. $\mathrm{He}$ will be remembered by all who knew him for a long time to come. He leaves a widow and two daughters. L. Gosland 